\title{
A Qualitative and Quantitative Study of Few Enzymes in the Liver of Cadmium Fed Rats
}

\author{
S.V.S. RANA, V.P. AGRAWAL and N.G. BHARDWAJ \\ School of Environmental Contamination \& Toxicology, \\ D.A.V. College, Muzaffarnagar-251001, India
}

(Received January 24, 1983 and in revised form April 20, 1983)

\begin{abstract}
Cadmium when administered to animals is known to accumulate in the liver and kidney, causing identifiable toxic effects. These effects on enzyme systems have been described in the present investigation selecting few of them viz. alkaline phosphatase, acid phosphatase, glucse-6-phosphatase and cholinesterase in the liver of rat, Rattus rattus albino. Topographical study on dysenzymia thus made have been found helpful in manifesting further the mechanism of $\mathrm{Cd}$ toxicity. Variations in the level of enzyme protein, state of cellular organelle together with processes of phosphorylation, adenylation and oxidative phosphorylation have been discussed explaining the cause and significance of these changes in enzyme activity.
\end{abstract}

Key words : Enzymes-Liver-Cadmium-Rat

\section{INTRODUCTION}

The retention of $\mathrm{Cd}$ in the liver is related to its selective storage in a proteinmetallothionein, however, as accumulation increases there is spillage of $\mathrm{Cd}$ to other proteins and toxicity appears ${ }^{1)}$. A sailent feature of $\mathrm{Cd}$ metabolism is its powerful interaction with other divalent metal ions particularly in the liver and kidney. In vivo and in vitro studies of its effects on brush border enzymes ${ }^{2}$, hepatic detoxication enzymes ${ }^{3)}$ and nine other enzymes ${ }^{4)}$ have already been made. However, visual evidences on dysenzymia are not available. Present attempt describes the qualitative and quantitative modification of alkaline phosphatase, acid phosphatase, glucose-6-phosphatase and cholinesterase thus caused by $\mathrm{Cd}$ in the liver of rats. Enzymological changes have been discussed in terms of changes in the micro-environment of the cell, formation of apoenzymes, metal protein complexes and oxidative phosphorylation etc.

\section{Materials AND Methods}

Forty adult male rats (Rattus rattus albino), two months old and weighing $100 \pm 10 \mathrm{gm}$ were selected from the laboratory stock. At random the groups were 
formed, each containing twenty rats. They were housed individually in suitable cages, fed on laboratory diet (Hindustan Lever Ltd., Bombay) and tap water ad libitum. Rats of group A were administered cadmium sulphate (BDH mol. wt. 769.51 ), at $0.5 \mathrm{gm} / \mathrm{kg}$ body weight by gavage on each day for thirty days. Rats of group B served laboratory diet alone were used as controls.

On 31st day, all the rats were starved for 24 hours and then sacrificed by decapitation. For histochemical study small pieces of liver from each rat were fixed in chilled absolute acetone, frozen for few hours and cut on a freezing microtome. Paraffin sections (whenever applicable), were also processed for alkaline phosphatase ${ }^{5)}$, acid phosphatase $^{6}$, glucose-6-phosphatase ${ }^{7)}$ and cholinesterase $^{8)}$. Rest of the liver lobes were quickly excised and immediately
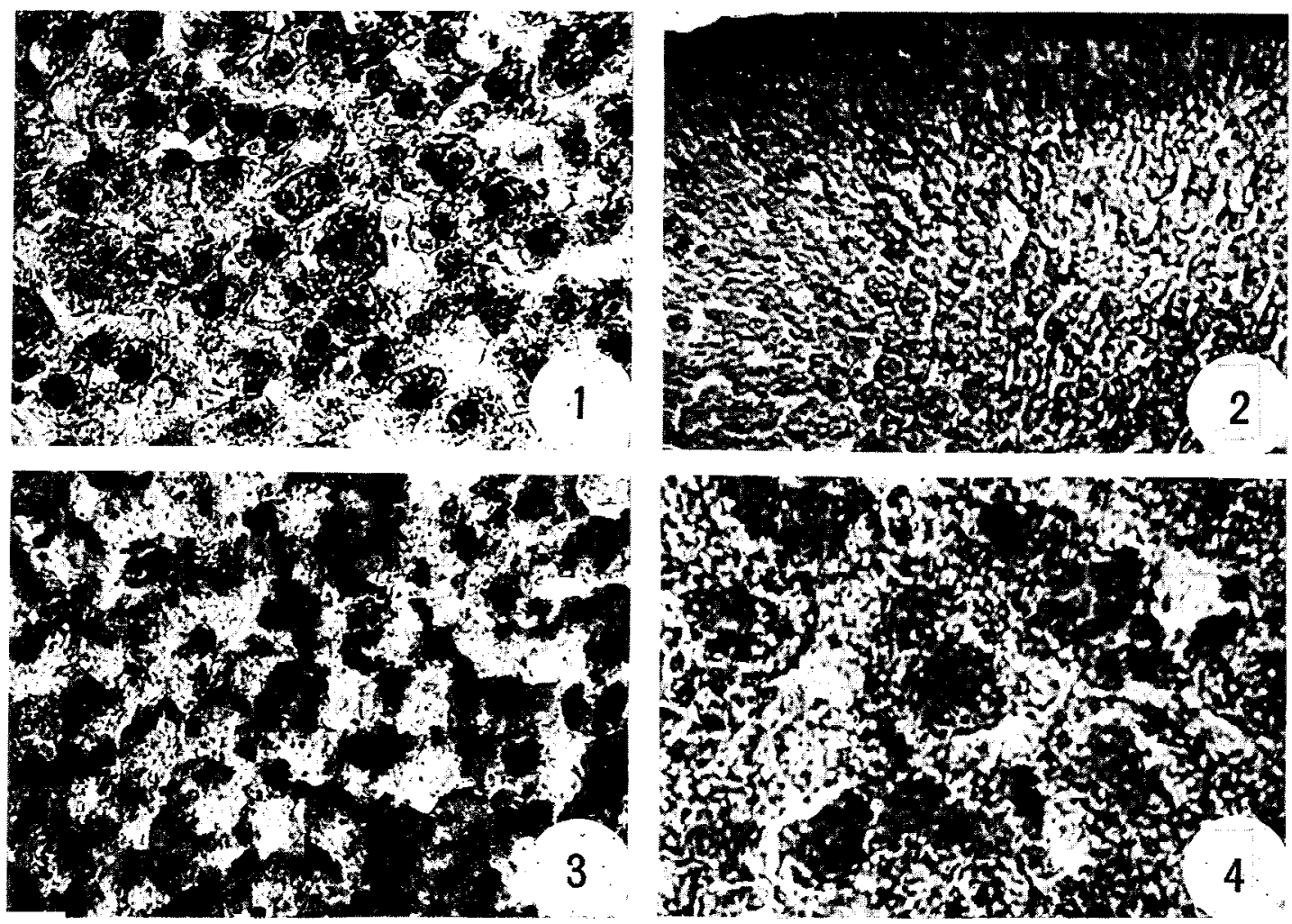

Fig. 1. A uniform reaction for alkaline phosphatase is exhibited by the entire hepatic parenchyma of control rat. $\times 320$

Fig. 2. After cadmium treatment only the perilobular region could show the presence of alkaline phosphatase. $\times 125$

Fig. 3. A strong reaction for acid phosphatase was observed in liver of control rat. $\times 320$

Fig. 4. Liver from a $\mathrm{Cd}$ fed rat shows a diffused reaction throughout the lobule. $\times \mathbf{5 0 0}$ 
frozen at $-4^{\circ} \mathrm{C}$. $10 \%(\mathrm{w} / \mathrm{v})$ homogenate was prepared in $0.25 \mathrm{M}$ ice-cold sucrose solution at $0^{\circ} \mathrm{C}$. The homogenate was centrifuged for $20 \mathrm{~min}$ at $1500 \mathrm{~g}$ and the clear supernatant fluid was used as the source of enzymes. Alkaline and acid phosphatases were determined using sodium- $\beta$-glycerophosphate as substrate ${ }^{9)}$. For the estimation of glucose-6-phosphatase, $0.01 \mathrm{M}$ glucose-6-phosphate solution was incubated with homogenates for $15 \mathrm{~min}$ at $\mathrm{pH} 6.5^{10)}$. Cholinesterase activity was determined by the method of Rappaport et al. ${ }^{11}$ The protein contents in the homogenates were determined using bovine serum albumin as standard ${ }^{12)}$. For each enzyme, triplicate samples were analysed and the incubations were repeated three times. The Fisher ' $t$ ' test ${ }^{13)}$ was employed for statistical significance.
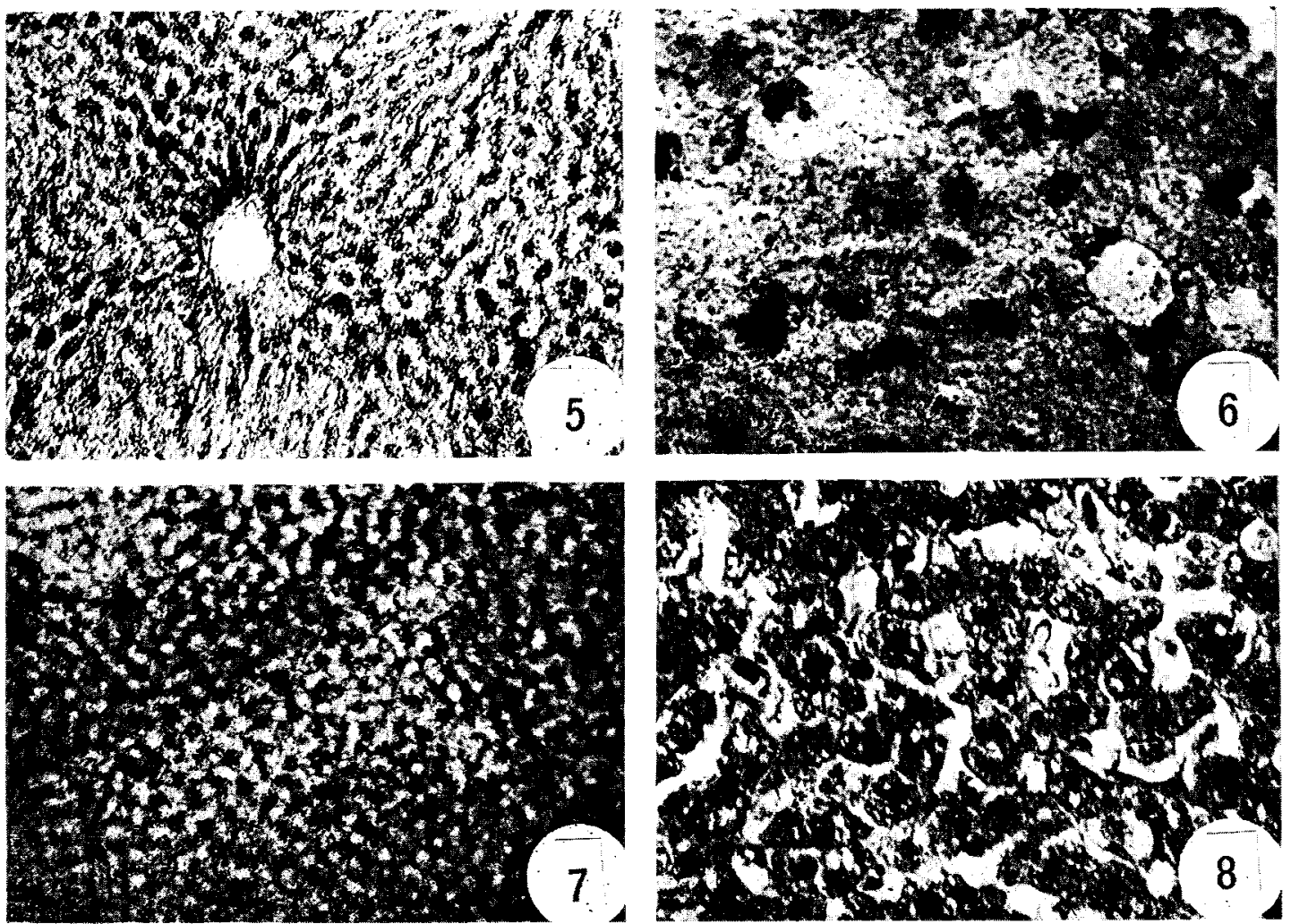

Fig. 5. Fresh frozen section of liver from a control rat shows glucose-6-phosphatase rich parenchyma. $\times 320$

Fig. 6. In Cd fed rats only the nuclei show a dull reaction for glucose-6-phosphatase. $\times \mathbf{3 2 0}$

Fig. 7. A moderate reation for cholinesterase was visualized in the entire lobule of control rat. $\times \mathbf{3 2 0}$

Fig. 8. Liver of $\mathrm{Cd}$ fed rat shows a dull but uniform reaction for cholinesterase. $\times 80$ 
Table 1. Enzyme activities in liver of cadmium fed and control rats

\begin{tabular}{|c|c|c|c|c|c|c|c|c|c|c|}
\hline \multirow{2}{*}{ S. No. } & \multirow{2}{*}{ Enzymes } & & \multicolumn{4}{|c|}{ Treated liver } & \multicolumn{4}{|c|}{ Control liver } \\
\hline & & & I & II & III & IV & I & II & III & IV \\
\hline 1. & Alkaline phosphatase & & - & - & - & + & + & - & + & + \\
\hline 2. & Acid phosphatase & & \pm & - & \pm & \pm & + & - & \pm & $H$ \\
\hline 3 . & Glucose-6-phosphatase & & $\mathrm{n} \pm$ & - & $\mathrm{n} \pm$ & $\mathrm{n} \pm$ & + & - & + & + \\
\hline 4. & Cholinesterase & & \pm & - & \pm & \pm & + & - & + & + \\
\hline $\mathbf{H}$ & epatic parenchyma & $H$ & Strong & & & & & & & \\
\hline II & ile Canaliculi & + & Moder & & & & & & & \\
\hline III $\mathrm{C}$ & entrolobular region & \pm & Weak & & & & & & & \\
\hline IV $\mathrm{Pe}$ & erilobular region & $\mathrm{n}$ & Only & Hu & & & & & & \\
\hline
\end{tabular}

Table 2. Enzyme activity in the liver of control and treated rats

\begin{tabular}{lccc}
\hline \multicolumn{1}{c}{ Enzymes } & Control & Cadmium treated & Sign. Diff. \\
Alkaline phosphatase ${ }^{\mathrm{b}}$ & $0.38 \pm 0.020^{\mathrm{a}}$ & $0.22 \pm 0.03$ & $5.7142(+)$ \\
Acid phosphatase $^{\mathrm{b}}$ & $0.43 \pm 0.012$ & $0.38 \pm 0.01$ & $5.0000(+)$ \\
Glucose-6-phosphatase $^{\mathrm{b}}$ & $0.72 \pm 0.026$ & $0.64 \pm 0.02$ & $0.3900(-)$ \\
Cholinesterase units $^{-}$ & $42.00 \pm 5.23$ & $18.00 \pm 1.53$ & $11.3900(+)$
\end{tabular}

a Values are mean \pm S.E. of 3 observations.

b Activity is expressed in mg of inorganic phosphate librated per $\mathrm{mg}$ of protein $/ \mathrm{h}$ at $37^{\circ} \mathrm{C}$.

$(+)$ Indicate statistically significant difference from control at $95 \%$ confidence interval.

\section{RESUlts}

A uniform reaction for alkaline phosphatase was exhibited by hepatic parenchyma of the centrolobular and periportal zones in control rats (Fig. 1). Cadmium largely inhibited its activity, however, perilobular parenchymal cells could show a dull activity (Fig. 2). For acid phosphatase, as usual, a strong reaction was exhibited by the hepatic cells (Fig. 3), however, in the liver of cadmium fed rats, a diffused reaction was observed throughout the liver lobule (Fig. 4). Glucose-6-phosphatase could very well be localized in the entire hepatic parenchyma (Fig. 5). In Cd fed rats, a dull and diffused reaction was exhibited only by the nuclei (Fig. 6). Cholinesterase too was inhibited by cadmium. In normal rats, a moderate reaction was recorded in the entire lobule (Fig. 7), but a dull reaction was observed in $\mathrm{Cd}$ fed rats (Fig. 8). Topographical differences on the distribution and intensity of these enzymes have been presented by Table 1 .

Quantitative data as presented in Table 2 supported histochemical observations. All the enzymes were inhibited significantly in the liver by $\mathrm{Cd}$ whereas an insignificant decline was noticed in the activity of glucose-6-phosphatase only.

\section{Discussion}

Accumulation of $\mathrm{Cd}$ in the liver is roughly proportional to dosage level ${ }^{14)}$. The 
appearance of lessions depends on liver Cd level. Structural changes have also been observed in the kidney, liver, gastrointestinal tract, heart, testis, pancreas, bones and blood vessels ${ }^{15-18)}$. However, mechanisms of that injury are not fairly known. Since, enzyme histochemistry is a link between morphology and chemistry, and enzyme proteins are first target of metal ions, few key enzymes were localized in the liver of $\mathrm{Cd}$ fed rats. It inhibited all of them without exception. Cadmium might have inhibited these enzymes by: (i) the removal of the essential metal ions leaving the apo-enzyme, (ii) the replacement of some of the protein groups giving mixed enzyme inhibitor metal complex. However, $\mathrm{Cd}$ induced injury to membranes through a characteristic change in the micro-environment of the cell needs further mention. Inhibition of alkaline phosphatase indirectly reflects an injury to plasma membrane. How the plasma membrane of perilobular parenchyma remained intact is a subject of further research. However, the fact that histological lesions were also not significant in the perilobular region support this observation. Dull and diffuse reaction for acid phosphatase reflects lysosomal leakage. A change in glucose-6-phosphatase activity probably points to changes in carbohydrate metabolism. The mechanisms behind chemical modification of enzymes might be phosphorylation, adenylation, ADP ribosylation, oxidation of thiol groups or respective reverse reactions ${ }^{19)}$ nevertheless, all these reactions need to be established for metal ions. A balance between synthesis and degradation of the enzyme protein might also be modified by nutritional variables ${ }^{20}$. Presumably, both variations in the level of enzyme protein and state of cellular organelle should be implied to interpret these changes in enzyme activity.

\section{REFERENCES}

1) Bremner, I.Q. (1977). In "Trace Elements in Human and Anımal Nutrition" (Edited by Underwood, E.J.), p. 244, Acad. Press, New York.

2) Sugawara, N., Sugawara, E. (1974). Effect of cadmium in vıvo and in vitro, on intestinal brush border. AlPase and ATPase. Bull. Environ. Contam. Toxicol. 14, 653.

3) Wagstaff, D.D. (1973). Stimulation of liver detoxication enzymes by dietary cadmium acetate. Bull. Environ. Contam. Toxicol. 10, 328.

4) Sporn, A., Dinu, I., Stoenescu, L., Ciystea, A. (1969). Detection of interactions between Cd and Zn. Nahrung, 13, 461.

5) Burstone, M.S. (1962). Enzyme Histochemistry and Its Application to the Study of Neoplasms. p. 274, Acad. Press, New York.

6) Gomori, G. (1941). Distribution of acid phosphatase under normal and pathologic conditions. Arch. Pathol. 32, 188.

7) Chiquoine, A.D. (1953). Distribution of glucose-6-phosphatase in the liver and kidney of mouse. J. Histochem. Cytochem., 1, 429.

8) Koelle, G.B., Periendenwald, J.S. (1949). Histochemical method for localizing cholinesterase activity. Proc. Soc. Exp. Biol. and Med., 70, 617.

9) Morton, R.K. (1955). Methods of extraction of enzyme from animal tissues. In: Methods in Enzymology (Colowick, S.P. and Kaplan, N.O. eds.) Vol. I, p. 25, Academic Press, New York. 
10) Swanson, M.A. (1965). In "Methods in Enzymology (Edited by Colowick, S.P. and Kaplan, N.O.), Vol. II, p. 149, Acad. Press, New York.

11) Rappaport, F., Fischl, I. and Pinto, N. (1959). An improved method for the estimation of cholinesterase activity in serum. Clin. Chim. Acta, 4, 227.

12) Lowry, O.H., Rosenbrough, N.J., Farr, A.L. and Randall, R.J. (1951). Protein measurement with the Folin phenol reagent. J. Biol. Chem. 198, 265.

13) Fisher, R.A. (1950). Statistical Methods for Research Workers, 11th ed. Oliver and Boyd. London.

14) Winge, D., Krasn, O.J. and Colucci, A.V. (1974). In "Trace Element Metabolism in Animals" (Hoekstra, W.S. et al. Eds.), University Park Press, Baltimore, Maryland, Vol. 2, p. 500 .

15) Itokawa, Y.T. and Tanaka, S. (1973). Bone changes in experimental chronic cadmium poisoning. Arch. Environ. Health. 26, 241.

16) Schroeder, H.A. (1965). Cadmium as a factor in hypertension. J. Chron. Dis., 18, 647.

17) Stowe, H.W., Wilson, M. and Goyer, R.A. (1977). In "Trace Elements in Human ana Animal Nutrition" (Underwood, E.J., 4th Ed.), p. 250. Academic Press, New York.

18) Wilson, R.H., De EDS, F. Cox, A.J. (1977). In “Trace Elements in Human and Animal Nutrition" (Edited by Underwood, E.J.), p. 250. Academic Press, New York.

19) Holzer, H. and Duntze, W. (1971). Metabolic regulation by chemical modification of enzymes. Ann. Rev. Biochem. 40, 345.

20) Schimke, R.T., Dehlinger, P.J. (1972). Turnover of membrane proteins of animal cells. In "Membrane Research" (Edited by Fox, C.F.), p. 115, Academic Press, New York. 